\title{
Effects of Selenium Deficiency in the Environment on Antioxidant Systems of Wumen Semi-Fine Wool Sheep
}

\author{
Bin Huo ${ }^{1}$, Ting Wu${ }^{1}$, Chunjie Song ${ }^{1}$, Xiaoyun Shen ${ }^{1,2,3 *}$ \\ ${ }^{1}$ School of Life Science and Engineering, Southwest University of Science and Technology, Mianyang, China \\ ${ }^{2}$ State Engineering Technology Institute for Karst Desertification Control, Guizhou Normal University, Guiyang, China \\ ${ }^{3}$ World Bank Poverty Alleviation Project Office in Guizhou, Southwest China, Guiyang, China
}

Received: 15 April 2019

Accepted: 18 May 2019

\begin{abstract}
The Wumeng semi-fine wool sheep industry is the pillar industry in the Wumeng mountainous area. The objective of this study was to explore the effects of selenium deficiency in the environment on the mineral element metabolism and antioxidant system function in grazing Wumen semi-fine wool sheep, and provide scientific and objective data for the reference of the development of Wumen sheep industry. Samples of soil and forage were collected from affected and unaffected areas. Samples of tissue and blood were collected from affected and healthy sheep. The samples were used for hematological parameters and biochemical index analyses and mineral nutrient measurements. The results showed that concentrations of selenium (Se) in the soil and forage samples from the affected area were significantly lower than those from the unaffected area $(P<0.01)$. The selenium concentrations of blood, liver and wool samples from the affected sheep were significantly lower than those in the healthy sheep $(P<0.01)$. $\mathrm{Hb}, \mathrm{PCV}$ and $\mathrm{MCH}$ of the affected sheep were significantly lower than those in the healthy sheep $(P<0.01)$. Serum GSH-PX, CAT and T-AOC of the affected sheep were significantly lower than those in the healthy sheep $(P<0.01)$. Serum MDA, T-NOS, NO and LPO of the affected sheep were significantly higher than those in the healthy sheep $(P<0.01)$. Serum AKP, CPK, LDH, ALT, AST and A/G value of the affected sheep were significantly higher than those in the healthy sheep $(P<0.01)$. Serum total protein, albumin, $\alpha$-Globulin, $\beta$-Globulin and $\gamma$-Globulin concentrations of the affected sheep were significantly lower than those in the healthy sheep $(P<0.01)$. The study clearly demonstrated that grazing a seleniumdeficient meadow significantly reduces the selenium content of tissue and antioxidant capacity, which seriously caused oxidative damage of the Wumeng semi-fine wool sheep.
\end{abstract}

Keywords: Wumen semi-fine wool sheep, selenium deficiency, mineral nutrient, antioxidant systems, Wumeng mountainous area

*e-mail: kjxyshenxy@163.com 


\section{Introduction}

The Wumeng mountainous area encompasses the provinces of Sichuan, Yunnan and Guizhou, located at $100^{\circ} 33^{\prime}-106^{\circ} 50^{\prime}$ E longitude and $24^{\circ} 12^{\prime}-28^{\circ} 57^{\prime} \mathrm{N}$ latitude, at an average elevation of 1600-3000 $\mathrm{m}$ above sea level in a warm and humid climate, with annual precipitation $950 \mathrm{~mm}$ and relative humidity $70-80 \%$ [1]. The grassland vegetation is mainly Pоа апnиа L., Carex rigescens, Trifolium repens L., Festuca ovina L., Dactylis glomerata L., Lolium perenne L., and Potentilla fulgens [2, 3]. Grassland animal husbandry is the pillar industry and the advantageous industry in Wumeng mountainous area, which is the material basis for the survival and development of ethnic minorities in the area $[3,4]$.

Wumeng semi-fine wool sheep is a dualpurpose (wool and meat) new breed by crossbreeding with mountain Tibetan coarse wool sheep, Corriedale sheep, Merino sheep, Sinkiang semi-fine wool sheep and Lincoln sheep in the Wumen mountainous area [5]. The sheep has been cultivated for 44 years, uniting the efforts and sweat of several generations of scientists and technicians and filling the gaps in the animal species without artificial cultivation in Guizhou [5, 6]. The breeding herd of sheep has been formed with relatively good production performance and relatively stable heredity performance through up-grading from 1974 to 1982, crossing fixation from 1982 to 1990, expanding the herd from 1990 to 2007; heredity performance was completely stable by 2017 [5-7]. Wumeng semi-fne wool sheep have the characteristics of strong adaptability, rough feed resistance, early maturity, good meat performance, and high wool yield. The average body weights of adult rams and ewes were $61.62 \pm 5.38$ and $52.76 \pm 5.93 \mathrm{~kg}$ respectively, the average wool yields of adult rams and ewes were 5.86 \pm 1.27 and $4.72 \pm 1.13 \mathrm{~kg}$ respectively, its main fineness was $25.00-29.00 \mu \mathrm{m}$ and scouring yield was $57.72 \%$, and its production performance is obviously higher than other local breeds $[8,9]$. At present, the Wumeng semi-fne wool sheep industry is the characteristic industry in the Wumeng mountainous area, as well as the main source of local people's productive life information.

Selenium (Se) deficiency is one of the major environmental problems that endanger the development of grassland animal husbandry and the health of local people [10]. Selenium is an essential trace element for man and animals, which is a cofactor of selenoproteins participate in the defense against oxidative stress, muscle development and function, synthesis and metabolism of thyroid hormones [11]. Adequate levels of selenium are necessary for the elimination of free-radicals, bone metabolism, iodine metabolism, endocrine and immune function, and reproductive processes [12, 13]. Severe deficiency results in obvious symptoms such as white muscle disease in ungulates, osteopathy and Keshan disease in human, trophism hepatonecrosis in hogs, and dative diathesis in poultry [14-16].

The purpose of this study was to explore the effects of selenium deficiency in the environment on the mineral element metabolism and antioxidant system function of Wumen semi-fine wool sheep under natural grazing conditions, and provide scientific and objective data for the reference of the development of the Wumen semifine wool sheep industry in the Wumeng mountainous area.

\section{Materials and Methods}

The experiment was designed as a control experiment. The Zhaoyang County Pasture was selected as the experimental pasture (affected area), and the Weining County Breeding Sheep Farm was selected as the control pasture (unaffected area). The soil and forage samples of the control pasture and the experimental pasture were collected separately, and mineral element concentrations of soil and forage samples were analyzed. Animal tissues samples of Wumen sheep which were naturally grazing in the control pastures and experimental pastures were collected respectively, and mineral element concentrations in tissues, blood physiological, biochemical and antioxidant systems of sheep were analyzed.

\section{Animals}

Thirty Wumeng semi-fine wool 1-year-old rams were selected from Weining County $\left(26^{\circ} 48^{\prime} \mathrm{N}, 103^{\circ} 37^{\prime} \mathrm{E}\right)$ and Zhaoyang County $\left(27^{\circ} 28^{\prime} \mathrm{N}, 103^{\circ} 45^{\prime} \mathrm{E}\right)$ randomly, their weight was $37 \pm 3.5 \mathrm{~kg}$ and all of sheep from Weining County were judged to be in good health after clinical examination.

\section{Sample Collection}

\section{Wool and Blood Samples Collection}

Wool samples were taken from animals' necks and each sheep was collected $5 \mathrm{~g}$ approximately. Each sample was individually washed with shampoo and then washed five times with distilled water afterward, and kept in a desiccator over silica gel until analyzed.

Blood samples were obtained from the jugular vein using trace mineral-free vacutainer tubes, and $1 \%$ sodium heparin as anticoagulant for hematological examinations and mineral analysis. Blood samples were stored at $-20^{\circ} \mathrm{C}$ for analysis of trace elements. Anticoagulant tubes were kept at $4^{\circ} \mathrm{C}$ for up 4 hours until assay of hematology examination. Serum samples for biochemical analysis were separated by centrifuge (Rev: $3500 \mathrm{R} / \mathrm{min}, \mathrm{T}$ : $10 \mathrm{~min}$ ), and stored in an EP tube at $-80^{\circ} \mathrm{C}$ until analyzed. 


\section{Liver Biopsy Collection}

Liver samples of sheep were collected by liver biopsy. One day before surgery, these bleeding times, clotting times and prothrombin times of sheep were measured. On the day of surgery, the animal was intramuscularly injected with $10 \mathrm{mg}$ vitamin $\mathrm{K}$ using phenobarbital sodium and codeine of $0.03 \mathrm{~g}$ each to anesthetize before operation, and the puncture point, direction and depth were located by ultrasound. The operator used a rubber tube to connect the $20 \mathrm{~mL}$ syringe and the liver puncture needle, the syringe sucked 3-5 mL with aseptic saline and we cleaned the gas in the syringe. A puncture needle was used first to prick holes in the skin, and then a liver puncture needle was used to prick holes of $0.5-1 \mathrm{~cm}$ along the upper edge of the rib. The saline in the syringe was injected into $0.5-1 \mathrm{~mL}$ to wash out the skin and subcutaneous tissue that might have existed in the liver puncture needle cavity and avoid blockage of the needle. Drawing the needle bolt to $5-6 \mathrm{~mL}$ scale of syringe to cause and maintain negative pressure in the needle. At the moment of the animal holding its breath, the liver tissue was punctured vertically, and the depth of puncture was about 4-6 $\mathrm{cm}$. After pulling out the liver puncture needle, the puncture site was covered with aseptic gauze, pressed for a few minutes, fixed with adhesive plaster, placed with a sand bag to pressurize and tighten the abdominal belt, and the obtained liver tissue was injected into the specimen bottle to be fixed for inspection $[6,17]$.

\section{Soil Sample Collection}

Thirty soil samples from the surface layer $(0-30$ $\mathrm{cm}$ ) were randomly collected (each 15 in experimental and control group). The samples were collected using a $30 \mathrm{~mm}$ diameter cylindrical corer in quadrats of $1 \times 1 \mathrm{~m}$, one sample was composited by four soil cores collected at the site, and each sample was $200 \mathrm{~g}$, each quadrat interval was $100 \mathrm{~m}$. These soil samples were used to analyze the content of mineral elements and mark the sample points to prepare for collecting forage samples at the same location. The composite soil samples were dried at $25^{\circ} \mathrm{C}$ until constant weight, and screened by 200 mesh.

\section{Forage Sample Collection}

Thirty mixed forage samples were collected from randomly distributed locations (each 15 in experimental and control group). In order to reduce the influence of different herbage species on the mineral content, taking the soil sample point as the center of the circle, selecting 10 points evenly distributed $100 \mathrm{~m}$ from the center of the circle (each point was $200 \mathrm{~m}$ from each other), collecting $20 \mathrm{~g}$ herbage at each point, 10 points of mixed pasture from a $200 \mathrm{~g}$ sample of forage, herbage samples were cut $1-2 \mathrm{~cm}$ above the ground level for reduced soil contamination. The composite forage samples were dried at $25^{\circ} \mathrm{C}$ until constant weight.

\section{Sample Processing}

The microwave digestion method that was used to heat the digestion liquid in the closed container by microwave heating and each sample was quickly dissolved in the high temperature pressurization condition. The soil was heated by microwave heating with a hydrofluoric acid (HF), perchloric acid $\left(\mathrm{HClO}_{4}\right)$ and nitric acid $\left(\mathrm{HNO}_{3}\right)(5: 2: 5)$ mixture to dissolve the sample. The forage and animal tissues were heated by microwave heating with a nitric acid and perchloric acid (4:1) mixture to dissolve the sample [18].

\section{Mineral Content Analysis}

Concentrations of manganese (Mn), zinc ( $\mathrm{Zn})$, iron $(\mathrm{Fe})$, copper $(\mathrm{Cu})$, selenium $(\mathrm{Se})$, cobalt $(\mathrm{Co})$ and molybdenum (Mo) in the samples of soil, forage, wool, blood and liver were measured using inductively coupled plasma atomic emission spectroscopy (ICP-AES). The instrument used was an HK9600 inductively coupled plasma atomic emission spectrometer (Huaketiancheng Co., Ltd, China). The standard solutions of the studied ions were purchased from the National Center of Analysis and Testing for Nonferrous Metals and Electronic Materials, China.

\section{Hematological Examination}

We used an automated hematology analyzer for animals (SF-3000, Sysmex-Toa Medical Electronics, Kobe, Japan) to detect hemoglobin ( $\mathrm{Hb})$, red blood cell count (RBC), packed cell volume (PCV), mean corpuscular volume (MCV), mean corpuscular hemoglobin $(\mathrm{MCH})$, mean corpuscular hemoglobin concentration (MCHC), white blood cell count (WBC) and blood platelet (PLT) values.

\section{Biochemical Examination}

We used an automatic biochemical analyzer for animals (MindrayBS-420, China) to detect serum biochemical analyses, including creatine phosphokinase (CPK), lactate dehydrogenase (LDH), glutamate pyruvate transaminase (GPT), glutamic oxaloacetic transaminase (GOT), alkaline phosphatase (ALP), total protein (TP), albumin (ALB), globulin (GLOB), usea nitrogen (BUN), potassium $(\mathrm{K})$ and sodium $(\mathrm{Na})$. Serum superoxide dismutase (SOD), catalase (CAT), glutathione peroxidase (GSH-Px), malondialdehyde (MDA), total antioxidant capacity (T-AOC), total nitric oxide synthase (T-NOS), nitric oxide (NO) and lipid peroxide (LPO) were determined using commercial test kits (Nanjing Jiancheng Bio-Engineering Institute, China). 
Table 1. Mineral content in soil and forage $(\mu \mathrm{g} / \mathrm{g})$.

\begin{tabular}{|c|c|c|c|c|}
\hline \multirow{2}{*}{ Element } & \multicolumn{2}{|c|}{ Soil } & \multicolumn{2}{c|}{ Forage } \\
\cline { 2 - 5 } & Affected area & Unaffected area & Affected area & Unaffected area \\
\hline $\mathrm{Mn}$ & $168.42 \pm 14.23$ & $164.55 \pm 11.73$ & $53.86 \pm 5.12$ & $52.74 \pm 4.31$ \\
\hline $\mathrm{Zn}$ & $52.83 \pm 7.16$ & $55.35 \pm 6.22$ & $65.48 \pm 3.33$ & $68.57 \pm 4.14$ \\
\hline $\mathrm{Co}$ & $5.24 \pm 1.31$ & $5.75 \pm 1.63$ & $4.02 \pm 1.15$ & $9.05 \pm 1.37$ \\
\hline $\mathrm{Cu}$ & $26.37 \pm 3.12$ & $27.54 \pm 4.21$ & $9.17 \pm 1.20$ & $352 \pm 22.74$ \\
\hline $\mathrm{Fe}$ & $4548 \pm 78$ & $4624 \pm 62$ & $342 \pm 21.25$ & $0.15 \pm 0.02^{\mathrm{a}}$ \\
\hline $\mathrm{Se}$ & $0.043 \pm 0.01^{\mathrm{b}}$ & $0.17 \pm 0.03^{\mathrm{a}}$ & $0.042 \pm 0.01^{\mathrm{b}}$ & $2.20 \pm 0.25$ \\
\hline $\mathrm{Mo}$ & $2.79 \pm 0.24$ & $2.92 \pm 0.43$ & $2.15 \pm 0.27$ & \\
\hline
\end{tabular}

Note:

1. $\mathrm{Mn}=$ manganese, $\mathrm{Zn}=$ zinc, $\mathrm{Co}=$ cobalt, $\mathrm{Cu}=$ copper, $\mathrm{Fe}=$ iron, $\mathrm{Se}=$ selenium, $\mathrm{Mo}=$ molybdenum.

2. The same sample in the same row values with different capital letter superscripts mean significant differences $(P<0.05)$, and with different small letter superscripts mean highly significant differences $(P<0.01)$, while with the same or no letter superscripts mean no significant differences $(P>0.05)$, the same as below.

\section{Statistical Analyses}

Data were analyzed using the Statistical Package for the Social Sciences (SPSS, version 23.0, Inc., Chicago, Illinois, USA), and presented in the form of mean \pm standard error (SE). Significant differences between groups were assessed using Student's t-test with least significant differences of $1 \%(P<0.01)$ or $5 \%$ $(P<0.05)$.

\section{Results}

\section{Mineral Element Concentrations of Soil and Forage}

Concentrations of selenium in the soil and forage samples in the affected area were significantly lower than those in the unaffected area $(P<0.01)$. Other mineral contents had no significant difference
(Table 1). In general, selenium levels in the soil and forage lower than $0.1 \mu \mathrm{g} / \mathrm{g}$ should be insufficient for ruminants. Selenium levels in the soil lower than $0.040 \mu \mathrm{g} / \mathrm{g}$, and selenium levels in the forage lower than $0.050 \mu \mathrm{g} / \mathrm{g}$ should be seriously insufficient for ruminants.

\section{Effect of Selenium Deficiency on Animal Tissue Mineral Concentrations}

The selenium content of blood, liver and wool samples in the affected sheep were significantly lower than those in the healthy sheep $(P<0.01)$ (Tables 2 and $3)$. Concentrations of iron in the blood and liver samples in the affected sheep were significantly lower than those in the healthy sheep $(P<0.05)$. Concentrations of zinc and copper in the blood and liver samples in the affected sheep were significantly higher than those in the healthy sheep $(P<0.05)$ (Table 2).

Table 2. Mineral content in blood and liver samples $(\mu \mathrm{g} / \mathrm{g})$.

\begin{tabular}{|c|c|c|c|c|}
\hline \multirow{2}{*}{ Element } & \multicolumn{2}{|c|}{ Blood } & \multicolumn{2}{c|}{ Liver } \\
\cline { 2 - 5 } & Affected sheep & Healthy sheep & Affected sheep & Healthy sheep \\
\hline $\mathrm{Mn}$ & $0.62 \pm 0.11$ & $0.64 \pm 0.13$ & $4.50 \pm 0.47$ & $4.52 \pm 0.56$ \\
\hline $\mathrm{Zn}$ & $4.54 \pm 0.50^{\mathrm{A}}$ & $4.18 \pm 0.46^{\mathrm{B}}$ & $67.63 \pm 7.28^{\mathrm{A}}$ & $62.50 \pm 5.14^{\mathrm{B}}$ \\
\hline $\mathrm{Co}$ & $0.62 \pm 0.12$ & $0.64 \pm 0.16$ & $6.20 \pm 0.83$ & $6.38 \pm 0.95$ \\
\hline $\mathrm{Cu}$ & $1.92 \pm 0.36^{\mathrm{A}}$ & $1.50 \pm 0.22^{\mathrm{B}}$ & $125 \pm 21.64^{\mathrm{A}}$ & $105 \pm 14.82^{\mathrm{B}}$ \\
\hline $\mathrm{Fe}$ & $255 \pm 27.20^{\mathrm{B}}$ & $293 \pm 24.35^{\mathrm{A}}$ & $314 \pm 33.13^{\mathrm{B}}$ & $337 \pm 25.40^{\mathrm{A}}$ \\
\hline $\mathrm{Se}$ & $0.042 \pm 0.0025^{\mathrm{b}}$ & $0.15 \pm 0.012^{\mathrm{a}}$ & $0.055 \pm 0.011^{\mathrm{b}}$ & $0.24 \pm 0.051^{\mathrm{a}}$ \\
\hline $\mathrm{Mo}$ & $0.28 \pm 0.024$ & $0.29 \pm 0.015$ & $2.58 \pm 0.42$ & $2.44 \pm 0.32$ \\
\hline
\end{tabular}

Note: $\mathrm{Mn}=$ manganese, $\mathrm{Zn}=$ zinc, $\mathrm{Co}=$ cobalt, $\mathrm{Cu}=$ copper, $\mathrm{Fe}=$ iron, $\mathrm{Se}=$ selenium, $\mathrm{Mo}=$ molybdenum. 
Table 3. Mineral content in wool samples $(\mu \mathrm{g} / \mathrm{g})$.

\begin{tabular}{|c|c|c|}
\hline Item & Affected sheep & Healthy sheep \\
\hline $\mathrm{Mn}$ & $11.03 \pm 1.65$ & $10.84 \pm 1.73$ \\
\hline $\mathrm{Zn}$ & $121.42 \pm 17.15$ & $128.35 \pm 14.82$ \\
\hline $\mathrm{Co}$ & $2.15 \pm 0.52$ & $2.20 \pm 0.37$ \\
\hline $\mathrm{Cu}$ & $4.87 \pm 0.94$ & $4.53 \pm 0.73$ \\
\hline $\mathrm{Fe}$ & $324 \pm 14.55$ & $338 \pm 12.73$ \\
\hline $\mathrm{Se}$ & $0.053 \pm 0.011^{\mathrm{b}}$ & $0.16 \pm 0.014^{\mathrm{a}}$ \\
\hline $\mathrm{Mo}$ & $1.52 \pm 0.22$ & $1.60 \pm 0.21$ \\
\hline
\end{tabular}

Note: $\mathrm{Mn}=$ manganese, $\mathrm{Zn}=$ zinc, $\mathrm{Co}=$ cobalt, $\mathrm{Cu}=$ copper, $\mathrm{Fe}=$ iron, $\mathrm{Se}=$ selenium, $\mathrm{Mo}=$ molybdenum .

\section{Effect of Selenium Deficiency on Hematological Parameters}

The hematological values of animals are shown in Table 4. Hb, PCV and $\mathrm{MCH}$ of the affected sheep were significantly lower than those in the healthy sheep $(P<0.01)$. RBC, MCV, MCHC and PLT of the affected sheep were significantly lower than those in the healthy sheep $(P<0.05)$. There was no significant difference in WBC.

\section{Effect of Selenium Deficiency on Serum Biochemical Indexes}

The serum biochemical values of animals are given in Table 5. Serum AKP, CPK, LDH, ALT and AST of the affected sheep were significantly higher than those in the healthy sheep $(P<0.01)$. There were no significant differences in other biochemical indexes.

Table 4. Haematological values in sheep.

\begin{tabular}{|c|c|c|}
\hline $\begin{array}{c}\text { Hematological } \\
\text { indices }\end{array}$ & Affected sheep & Healthy sheep \\
\hline $\mathrm{Hb}(\mathrm{g} / \mathrm{L})$ & $85.24 \pm 5.26^{\mathrm{b}}$ & $120.62 \pm 7.13^{\mathrm{a}}$ \\
\hline $\mathrm{RBC}\left(10^{12} / \mathrm{L}\right)$ & $9.12 \pm 0.75^{\mathrm{B}}$ & $10.20 \pm 0.64^{\mathrm{A}}$ \\
\hline $\mathrm{PCV}(1 / \mathrm{L})$ & $29.05 \pm 1.24^{\mathrm{b}}$ & $36.45 \pm 2.73^{\mathrm{a}}$ \\
\hline $\mathrm{MCV}(\mathrm{fl})$ & $31.85 \pm 2.25^{\mathrm{B}}$ & $35.73 \pm 1.50^{\mathrm{A}}$ \\
\hline $\mathrm{MCH}(\mathrm{pg})$ & $9.35 \pm 0.72^{\mathrm{b}}$ & $11.83 \pm 0.94^{\mathrm{a}}$ \\
\hline $\mathrm{MCHC}(\%)$ & $29.34 \pm 1.40^{\mathrm{B}}$ & $33.09 \pm 1.27^{\mathrm{A}}$ \\
\hline $\mathrm{WBC}\left(\times 10^{9} / \mathrm{L}\right)$ & $9.38 \pm 0.52$ & $10.15 \pm 0.84$ \\
\hline $\mathrm{PLT}\left(\times 10^{9} / \mathrm{L}\right)$ & $382.20 \pm 32.35^{\mathrm{B}}$ & $432.54 \pm 34.28^{\mathrm{A}}$ \\
\hline
\end{tabular}

Note: $\mathrm{Hb}=$ hemoglobin, $\mathrm{RBC}=$ red blood cell count, $\mathrm{PCV}=$ packed cell volume, $\mathrm{MCV}=$ mean corpuscular volume, $\mathrm{MCH}=$ mean corpuscular hemoglobin, $\mathrm{MCHC}=$ mean corpuscular hemoglobin concentration, $\mathrm{WBC}=$ white blood cell count, PLT $=$ blood platelet.
Table 5. Serum biochemical indexes in sheep.

\begin{tabular}{|c|c|c|}
\hline Item & Affected sheep & Healthy sheep \\
\hline AKP (U/L) & $352.73 \pm 24.50^{\mathrm{a}}$ & $115.28 \pm 6.28^{\mathrm{b}}$ \\
\hline CPK (U/L) & $414.25 \pm 12.73^{\mathrm{a}}$ & $75.23 \pm 4.14^{\mathrm{b}}$ \\
\hline LDH (U/L) & $665.76 \pm 148.26^{\mathrm{a}}$ & $248.50 \pm 21.71^{\mathrm{b}}$ \\
\hline ALT (U/L) & $115.28 \pm 15.57^{\mathrm{a}}$ & $37.42 \pm 6.31^{\mathrm{b}}$ \\
\hline AST (U/L) & $247.40 \pm 7.47^{\mathrm{a}}$ & $74.25 \pm 3.46^{\mathrm{b}}$ \\
\hline $\mathrm{BUN}(\mathrm{mmol} / \mathrm{L})$ & $5.14 \pm 0.73$ & $4.86 \pm 0.51$ \\
\hline $\mathrm{K}(\mathrm{mmol} / \mathrm{L})$ & $4.36 \pm 0.34$ & $4.43 \pm 0.54$ \\
\hline $\mathrm{Na}(\mathrm{mmol} / \mathrm{L})$ & $134.65 \pm 21.32$ & $135.60 \pm 21.32$ \\
\hline
\end{tabular}

Note: $\mathrm{AKP}=$ alkaline phosphatase, $\mathrm{CPK}=$ creatine phosphokinase, $\mathrm{LDH}=$ lactate dehydrogenase, $\mathrm{ALT}=$ alanine aminotransferase, AST $=$ aspartate aminotransferase,

$\mathrm{BUN}=$ usea nitrogen, $\mathrm{K}=$ potassium, $\mathrm{Na}=$ sodium .

\section{Effect of Selenium Deficiency on Serum Antioxidant Indexes}

Serum antioxidant values of animals are shown in Table 6. Serum GSH-PX, CAT and T-AOC of the affected sheep were significantly lower than those in the healthy sheep $(P<0.01)$. Serum MDA, T-NOS, NO and LPO of the affected sheep were significantly higher than those in the healthy sheep $(P<0.01)$ (Table 6).

\section{Effect of Selenium Deficiency on Serum Protein Concentrations}

The serum protein concentration values of animals are given in Table 7. Serum total protein, albumin, $\alpha$-Globulin, $\beta$-Globulin and $\gamma$-Globulin concentrations of the affected sheep were significantly lower than those in the healthy sheep $(P<0.01)$. A/G value of the affected

Table 6. Serum antioxidant indexes in sheep.

\begin{tabular}{|c|c|c|}
\hline Item & Affected sheep & Healthy sheep \\
\hline GSH-PX $(\mathrm{U} / \mathrm{mL})$ & $29.24 \pm 2.31^{\mathrm{b}}$ & $68.34 \pm 2.67^{\mathrm{a}}$ \\
\hline SOD $(\mathrm{U} / \mathrm{mL})$ & $87.22 \pm 3.35$ & $85.50 \pm 5.33$ \\
\hline CAT $(\mathrm{U} / \mathrm{mL})$ & $5.56 \pm 0.41^{\mathrm{b}}$ & $9.33 \pm 0.92^{\mathrm{a}}$ \\
\hline T-AOC $(\mathrm{U} / \mathrm{mL})$ & $3.84 \pm 0.66^{\mathrm{b}}$ & $6.29 \pm 0.59^{\mathrm{a}}$ \\
\hline MDA $(\mathrm{nmol} / \mathrm{mL})$ & $83.75 \pm 9.26^{\mathrm{a}}$ & $21.13 \pm 5.29^{\mathrm{b}}$ \\
\hline T-NOS $(\mathrm{U} / \mathrm{mL})$ & $62.50 \pm 5.33^{\mathrm{a}}$ & $35.47 \pm 4.14^{\mathrm{b}}$ \\
\hline NO $(\mu \mathrm{mol} / \mathrm{mL})$ & $6.57 \pm 2.71^{\mathrm{a}}$ & $4.82 \pm 1.53^{\mathrm{b}}$ \\
\hline LPO $(\mathrm{mmol} / \mathrm{mL})$ & $3.73 \pm 0.52^{\mathrm{a}}$ & $1.52 \pm 0.33^{\mathrm{b}}$ \\
\hline
\end{tabular}

Note: $\mathrm{SOD}=$ superoxide dismutase, GSH-PX = glutathione peroxidase, $\mathrm{CAT}=$ catalase, $\mathrm{MDA}=$ malondialdehyde,

$\mathrm{T}-\mathrm{AOC}=$ total antioxidant capacity, $\mathrm{T}-\mathrm{NOS}=$ total nitric oxide synthase, $\mathrm{NO}=$ nitric oxide, $\mathrm{LPO}=$ lipid peroxide. 
Table 7. Serum protein concentrations in sheep.

\begin{tabular}{|c|c|c|}
\hline Parameter & Affected sheep & Healthy sheep \\
\hline Toal protein $(\mathrm{g} / \mathrm{L})$ & $54.16 \pm 4.52^{\mathrm{b}}$ & $72.97 \pm 5.72^{\mathrm{a}}$ \\
\hline Albumin $(\mathrm{g} / \mathrm{L})$ & $41.83 \pm 3.74^{\mathrm{b}}$ & $50.50 \pm 3.35^{\mathrm{a}}$ \\
\hline$\alpha$-Globulin $(\mathrm{g} / \mathrm{L})$ & $2.06 \pm 0.42^{\mathrm{b}}$ & $3.45 \pm 0.37^{\mathrm{a}}$ \\
\hline$\beta$-Globulin $(\mathrm{g} / \mathrm{L})$ & $3.15 \pm 0.45^{\mathrm{b}}$ & $5.23 \pm 0.56^{\mathrm{a}}$ \\
\hline$\gamma$-Globulin $(\mathrm{g} / \mathrm{L})$ & $7.12 \pm 0.83^{\mathrm{b}}$ & $13.79 \pm 1.22^{\mathrm{a}}$ \\
\hline $\mathrm{A} / \mathrm{G}$ & $3.39 \pm 0.31^{\mathrm{a}}$ & $2.25 \pm 0.24^{\mathrm{b}}$ \\
\hline
\end{tabular}

sheep were significantly higher than those in the healthy sheep $(P<0.01)$.

\section{Discussion}

Sheep and goats are the main livestock in the Wumeng mountainous area, where mineral element imbalance is widespread $[19,20]$. Therefore, the research on mineral element distribution characteristics of the system soil-pasture-animal have important significance for grassland animal husbandry development of the Wumeng mountainous area. In this investigation, the selenium concentrations of the soil and mixed pastures from the affected area were significantly lower than those from the unaffected area $(P<0.01)$, and it was also significantly lower than the lowest critical values required for humans and animals [21]. Grazing affected the meadow significantly by reducing the selenium content of blood, liver and wool, and significantly decreased the activity of antioxidant enzymes and induced anemia in sheep, which seriously affected the growth and development of the animals. At the same time, abortions and sudden death were seen in affected sheep.

Selenium is one of the essential trace elements for animals and performs numerous biological functions in animal organisms [11, 15]. At present, most animal and human studies have shown a significant relationship between selenium deficiency and anemia [22, 23]. Hematological parameters are used as indicators for evaluating anemia in animals [23]. In this study, the $\mathrm{Hb}, \mathrm{RBC}$ and PCV from the affected sheep were significantly decreased, which vindicates the fact that the affected sheep have anemia. Anemia in selenium deficiency is associated with increased generation of reactive oxygen species and exposure of erythrocytes to high degrees of oxidative stress [24-26]. Selenium is a key component of the active site of GSH-Px catalyzing the reduction of hydrogen peroxide and different organic peroxides. GSH-Px activity, which is responsible for the protection of hemoglobin in erythrocytes from oxidative stress, is diminished in selenium deficiency, causing increased lipid peroxidation of membrane lipids, denaturation of hemoglobin, and decreased osmotic resistance of erythrocytes. It causes hemolysis and reduced life-span of circulating erythrocytes in the affected sheep [27-29]. Moreover, a recent study has demonstrated inefficient erythropoiesis with defective erythroid differentiation and maturation in selenium-deficient animals [30-34]. Taken together, the development of anemia in sheep caused by selenium deficiency results from an excessive destruction of circulating erythrocytes along with a lack of sufficient production of mature erythroid cells.

The antioxidant system of an animal organism is a defensive system against free radical damage, including enzyme and non-enzyme systems [35]. The enzyme system consists of superoxide dismutase, glutathione peroxidase, catalase and other antioxidant enzymes. And the non-enzyme system consists of vitamin $C$, vitamin $\mathrm{E}$, glutathione, cysteine, copper, iron, zinc, selenium and other substances [36, 37]. The function of an antioxidant system in an organism is to scavenge excessive free radicals. Excessive free radical production or decreased function of an antioxidant system will result in a large excess of free radicals in the organism, which can cause damage to animal organisms [35]. SOD provides the efficient dismutation of $\mathrm{O}_{2}^{-}$into $\mathrm{H}_{2} \mathrm{O}_{2}$, which is scavenged by GSH-Px and CAT [38]. The biochemical function of GSH-Px is to reduce lipid hydroperoxides to their corresponding alcohols and to reduce free hydrogen peroxide to water [39]. Malondialdehyde is the most common product of lipid peroxidation, and its level can directly reflect the degree of lipid oxidative injury [40]. T-AOC is a comprehensive indicator for measuring antioxidant function of animal organisms. It can reflect the compensatory capacity to external stimuli and the metabolism capacity of free radicals in organisms. The decreased function of the T-AOC defense system can cause other diseases [41]. The expression level of NOS would increase and a large amount of NO would be released when the animal is in selenium deficiency for a long time, and the change of NO metabolism would cause organ damage [42]. When $\mathrm{H}_{2} \mathrm{O}_{2}$ is produced in large quantities, the content of LPO will increase, which cooperates with GSH-Px and CAT to decompose the intracellular $\mathrm{H}_{2} \mathrm{O}_{2}$ completely [42]. Thus, Serum SOD, GSH-Px, CAT and MDA are used as effective indicators for detecting the function of an antioxidant system in an organism [35, 42]. In this study, serum GSH-Px, CAT and T-AOC in selenium-deficient Wumen semi-fine wool sheep were significantly decreased, and serum levels of LPO, MDA, T-NOS and NO were significantly increased, which fully indicated that selenium deficiency induced the dysfunction of the antioxidant system and broke the relative balance between the oxidation and antioxidant systems, causing severe oxidative stress to organisms in the Wumen semi-fine wool sheep.

The reaction product of SOD is the substrate of GSH-Px [38]. The radical scavenging of $\mathrm{O}^{2-}$ requires continuous catalysis from SOD, GSH-Px, CAT and LPO [41, 42]. Therefore, SOD, GSH-Px and CAT plays a more important role in blocking membrane lipid peroxidation induced by free radicals. Zhao et al. 
(2004) deemed that selenium has a close relationship with SOD activity, but it is not a simple relationship of increasing and decreasing [43]. Low concentrations of selenium activate SOD activity, and high concentrations of selenium inhibit SOD activity. Therefore, when the selenium deficiency of the animal causes a decrease in the activity of GSH-Px, the living organism exhibits a compensatory increase in SOD activity in order to remove as much as possible the accumulation of free radicals due to a decrease in the activity of GSH-Px $[44,45]$. Rod et al. (2002) found that GSH-Px activity decreased and MDA content increased in selenium deficiency, but SOD activity increased instead of decreasing [46]. Peng (2009) found that the serum activities of GSH-Px, CAT and T-AOC decreased, MDA content increased, and there was no significant difference in SOD activity in selenium-deficient broiler chickens [47]. Cao et al. (2016) found that the activity of GSH-Px in plasma of selenium-deficient dairy cows was significantly decreased, which was positively correlated with selenium level, while the levels of MDA, T-NOS, CAT and LPO were significantly increased and negatively correlated with selenium level, but the activity of SOD was not significantly different [48]. In our study, serum GSH-Px, CAT, and T-AOC in selenium-deficient sheep were significantly decreased, and MDA content was significantly increased, which was consistent with the above results. But there was no significant difference in serum SOD activity. It may be that the compensatory function of SOD decreased due to the affected sheep grazing on selenium-deficient grassland for a long time. Serum AKP, ALT and AST are commonly used indicators for evaluating liver health in animals. And the serum activities of CPK and LDH are commonly used indicators to reflect the degree of damage to kidney and muscle $[49,50]$. The concentration of ALB varies with changes in forage protein. When the ALB concentration decreases it indicates protein deficiency in animals, and it may also be a decrease in albumin synthesis caused by liver disease [48]. Globulin is synthesized by the immune organs of an animal. Most of the globulin is produced outside the liver cells, which is related to the immunity of the organism $[48,51]$. Albumin and globulin complement each other to maintain a constant level of total protein [51]. In this study, the serum activity of GOT and GPT in the affected sheep increased, indicating that the liver cells of selenium-deficient sheep were damaged and the permeability was increased. The increase of LDH, ALP and CPK activity indicated that the muscle and kidney cells of selenium-deficient sheep were damaged. Serum $\mathrm{TP}$, ALB, and globulin were significantly reduced, indicating that the selenium sheep immune system was inhibited. The main cause of damage to liver, kidney and muscle caused by selenium deficiency is related to the weakening of antioxidant systems [52, 53]. Excessive accumulation of oxygen-free radicals in the organism causes a decrease in and conformational changes to cell mitochondrial membrane-bound enzymes, cytochrome $\mathrm{C}$ oxidase (CCO) and cardiolipin (CL), resulting in decreased activities of mitochondrial respiratory chain and mitochondrial energy conversion disturbance [5458]. Dysfunction and inhibition of mitochondrial ATP synthesis, structural denaturation and dysfunction of contractile proteins, and peroxidation of cell membranes, etc. - leading to muscle necrosis, and renal and hepatic injury in animals.

\section{Ethics Statement}

The Wumeng semi-fine sheep used in these studies were cared for as per outlined in the Guide for the Care and Use of Animals in Agricultural Research and Teaching Consortium (Federation of Animals Science Societies, 2010). Sample collections were approved by the Southwest University of Science and Technology in China, Institutional Animal Care and Use Committee (Project A00558).

\section{Acknowledgements}

This work was supported by the Project of National Key Research and Development Program of China in the $13^{\text {th }}$ Five-Year Plan (No. 2016YFC0502601), the National Natural Science Foundation of China (No. 41671041) and the Research Fund for the Doctoral Program of Southwest University of Science and Technology (No. 17zx7146).

\section{Conflict of Interest}

The authors declare no conflict of interest.

\section{References}

1. LIAO J.J., SHEN X.Y., HUO B., XIONG K.N. Effect of nitrogenous fertilizer on the antioxidant systems of grassland species in the Karst mountains. Acta Prataculturae Sinica, 27 (01), 169, 2018.

2. WU T., HUO B., CHI Y.K., SHEN X.Y. Chronic copper poisoning of Wumeng semi-fine wool sheep. Journal of Northwest A and F University (Natural Science Edition), 2 (08), 2, 2019.

3. SHEN X.Y., CHI Y.K., HUO B., WU T., XIONG K.G. Effect of fertilization on ryegrass quality and mineral metabolism in grazing the Wumeng semi-fine wool sheep. Fresenius Environmental Bulletin, 27 (10), 6824, 2018.

4. SONG S.Z., XIONG K.N., CHI Y.K., SHEN X.Y., GUO T., LU N.N. Research progress and prospect of grassland establishment and ecological animal husbandry in the karst rocky desertification area. Fresenius Environmental Bulletin, 27 (10), 7017, 2018.

5. LI L.J., SHEN X.Y. Development progress and breeding status of Guizhou semi-fine-wool sheep. Guizhou Agricultural Science, 38 (11), 182, 2010. 
6. CHI Y.K., XIONG K.N., CHEN H., MIN X.Y., XIAO H., LIAO J.J., SHEN X.Y. Effect of grazing to copper pollution meadow on copper metabolism in Wumeng semi-fine wool sheep. Polish Journal of Environmental Studies, 28 (3), 2, 2019.

7. SHEN X.Y., ZHANG M., XIONG K.N. Effected of molybdenum on sulfur metabolism in Guizhou sem-fine wool sheep in south west China karst mountain area. Journal of Animals and Veterinary Advance, 13 (17), 1027, 2014.

8. CHI Y.K., XIONG K.N., XIAO H., HUANG D.H., WEN Y.Q., SHEN X.Y. A comparative study on meat quality between Guizhou semi-fine wool sheep and a series of semi-fine wool sheep in southwest China. Fresenius Environmental Bulletin, 27 (6), 4238, 2018.

9. SHEN X.Y. Studies on wool-eating ailment in Guizhou semi-fine wool sheep. Agricultural Sciences in China, 10 (10), 1618, 2011.

10. CHEN Y.L., WANG H., SHI W.X. Study on the selenium and chromium of environment and human among the endemic areas of Yunnan unknown-cause sudden death. Modern Preventive Medicine, 36 (18), 3557, 2009.

11. GHADERZADEH S., MIRZAEI A.G.F., NIKBIN S. Review on properties of selenium in animal nutrition. Iranian Journal of Applied Animal Science, 6 (4), 753, 2016.

12. ROTRUCK J.T., POPE A.L., GANTHER H.E. Selenium: biochemical role as a component of glutathione peroxidase. Science, 38 (8), 280, 2010.

13. MUEGGE C.R., BRENNAN K.M., SCHOONMAKER J.P. Supplementation of organic and inorganic selenium to late gestation and early lactation beef cows effect on cow and preweaning calf performance. Journal of Animal Science, 94 (8), 3399, 2016.

14. LI Q., ZHAO Z.J., YANG P.Z. The prevention effect of selenium on prevalence of children kaschin-beck disease in active endemic areas in Qinghai plateau. Biological Trace Element Research, 169 (1), 17, 2016.

15. ZHAO B., ZHOU S.B., WU X.G., XING K., ZHU Y.Y., HU L., TAO X. Distribution and accumulation of selenium in plants and health risk assessment from a selenium-rich area in China. Polish Journal of Environmental Studies, 27 (6), 2873, 2018.

16. LI T.Y., YUAN X.Y., SONG Y.X., CHEN H.Y., LIU Q., HU S. Influence of heavy metals and nutrient concentrations on selenium geochemical behavior in soilrice system. Polish Journal of Environmental Studies, 25 (1), 185, 2016.

17. ARTHINGTON J.D., CORAH L.R. Liver biopsy procedures of animals; part II (Video, AI 8134). extension $\mathrm{TV}$, dept. of communications, cooperative extension service, Kansas State Univ, Manhattan 1995.

18. ZHANG X.H., WAN D.J., TIAN H.X., WX H.E., WANG Z.Q., LIU Q. Pollution assessment of heavy metals in soils and plants around a molybdenum mine in central China. Polish Journal of Environmental Studies, 28 (1), 125, 2019.

19. LUO J.C., ZHOU M., WANG Z.L., ZHANG Y. Fluxion and regulation of selenium in soil, plants, and animals in grassland grazing system. Pratacultural Science, 34 (4), 869, 2017.

20. SHEN X.Y., XIONG K.N., CHEN Y.B., ZHANG M., WANG X.L. Effect of fenced pasture on mineral metabolic in grazing semi-fine wool sheep in the karst mountain areas of southwest China. Journal of Animal and Veterinary Advances, 12 (10), 982, 2013.
21. SHEN X.Y., HUO B., MIN X.Y. Assessment of mineral nutrition of forage in the natural habitat of Przewalski's gazelle (Procapra przewalskii). Acta Prataculturae Sinica, 27 (3), 108, 2018

22. PETKOVA M.T.V., RUSEVA B.K., ATANASOVA B.D. Selenium deficiency as a risk factor for development of anemia. Journal of Biomedical and Clinical Research, 10 (1), 9, 2017.

23. WANG X., WANG Y., QING H.Y. Effects of different doses of selenium protein powder on hematological variables and blood biochemistry indices of rats. China Animal Husbandry and Veterinary medicine, 41 (07), 148, 2014.

24. KAUSHAL N., HEGDE S., LUMADUE J., PAULSON R.F., PRABHU K.S. The regulation of erythropoiesis by selenium in mice. Antioxid Redox Signal, 14 (8), 1403, 2011.

25. MUHAMMAD S., MUHAMMAD Y., KHAN M.R., AFTAB A.A., MUHAMMAD A., SYED E.H., MUHAMMAD K.R., MUHAMMAD A. Assessing lead $(\mathrm{Pb})$ residues in Lohi sheep and its impact on hematological and biochemical parameters. Polish Journal of Environmental Studies, 27 (4), 1721, 2018.

26. EIBOSHY M.E., RISHA E.F., ABDELHAMID F.M. Protective effects of selenium against cadmium induced hematological disturbances, immunosuppressive, oxidative stress and hepatorenal damage in rats. Journal of Trace Elements in Medicine and Biology, 29, 104, 2015.

27. HORKY., PAVEL. Influence of increased dietary selenium on glutathione peroxidase activity and glutathione concentration in erythrocytes of lactating sows. Annals of Animal Science, 14 (4), 869, 2014.

28. PILARCZYK B., TOMZAMARCINIAK A., STANKIEWICZ T. Serum selenium concentration and glutathione peroxidase activity and selenium content in testes of Polish Konik horses from selenium deficient area in North-Western Poland. Polish Journal of Veterinary Sciences, 17 (1), 165, 2014.

29. ZHAO J., XING H., LIU C. Effect of selenium deficiency on nitric oxide and heat shock proteins in chicken erythrocytes. Biological Trace Element Research, 171 (1), 208, 2016.

30. LIAO C., HARDISON R.C., KENENTT M.J. Selenoproteins regulate stress erythroid progenitors and spleen microenvironment during stress erythropoiesis. Blood, 131 (23), 2568, 2018.

31. KWON T.H., HAN Y.H., HONG S.G., LEE D.J., HA H.L., KANG S.W., LI W., YOON D.Y, YU D.Y. Reactive oxygen species mediated DNA damage is essential for abnormal erythropoiesis in peroxiredoxin II mice. Biochem Biophys Res Commun, 424 (1), 189, 2012.

32. LIAO C., CARLSON B.A., PAULSON R.F. The intricate role of selenium and selenoproteins in erythropoiesis. Free Radical Biology and Medicine, 127 (1), 165, 2018.

33. FRANCESCHI L.D., BERTOLDI M., FALCO L.D., SANTOS F., RONZINI L., TURRINI F., COLANCECCO A., CAMASCHELLA C. Oxidative stress modulates heme synthesis and induces peroxiredoxin-2 as a novel cytoprotective response in betathalassemic erythropoiesis. Haematologica, 96 (11), 1595, 2011.

34. HAN Y.H., KIM S.U., KWON T.H., LEE D.S., HA H.L., PARK D.S., WOO E.J., LEE S.H., KIM J.M., CHAE H.B., LEE S.Y., KIM B.Y. Peroxiredoxin II is essential for preventing hemolytic anemia from oxidative stress through maintaining hemoglobin stability. Biochem Biophys Res Commun, 426 (3), 427, 2012. 
35. SHEN X.Y. Effect of nitrogenous fertilizer treatment on mineral metabolism in grazing yaks. Agricultural Science in China, 8 (3), 361, 2009.

36. SHEN X.Y., DU G.Z., Li H. Studies of naturally occurring molybdenum-induced copper deficiency in the yaks. The Veterinary Journal, 171 (2), 352, 2006.

37. LIU D.D., LI H.I., WANG Y.Z., YING Z.Z., BIAN Z.W., ZHU W.L., LIU W.E.I., YANG L.F., JIANG D.H. How exogenous selenium affects anthocyanin accumulation and biosynthesis-related gene expression in purple lettuce. Polish Journal of Environmental Studies, 26 (2), 722, 2017.

38. XIE Z.Z., LIU Y., BIAN J.S. Hydrogen sulfide and cellular redox homeostasis. Oxidative Medicine and Cellular Longevity, 2016, 2, 2016.

39. COZZA G., ROSSETTO M., BOSELLO T.V. Glutathione peroxidase 4-catalyzed reduction of lipid hydroperoxides in membranes: The polar head of membrane phospholipids binds the enzyme and addresses the fatty acid hydroperoxide group toward the redox center. Free Radical Biology and Medicine, 112, 2, 2017.

40. LIANG J.B., YANG K.L, ZHANG Y.S. Effects of SOD Activities and MDA level about selenium deficiency in jejunum tunica mucosa of chickens. Chinese Journal of Veterinary Medicine, 53 (03), 29, 2017.

41. ZENG T., LI J.J., WANG D.Q. Effects of heat stress on antioxidant defense system, inflammatory injury, and heat shock proteins of Muscovy and Pekin ducks: evidence for differential thermal sensitivities. Cell Stress and Chaperones, 19 (6), 895, 2014.

42. GEORGIEVA N.V., STOYANCHEV K., BOZAKOVA N. Combined effects of muscular dystrophy, ecological stress, and selenium on blood antioxidant status in broiler chickens. Biological Trace Element Research, 142 (3), 532, 2011.

43. ZHAO X.Y., LIU Y.N., WANG X.Z., ZHAO H.W. Effects of microelements Se, Mn, and F on SOD activity. Journal of the Third Military Medical University, 26 (2), 171, 2004.

44. DONALDSON W.E. Effects of dietary lead, cadmium, mercury, and selenium on fatty acid composition of blood serum and erythrocyte membranes from chicks. Biological trace element research, 7 (4), 255, 1985.

45. TONG Z.X., KANG S.L., WU R. Advances of researches on biological effects of selenium and selenoproteins. Progress in Veterinary Medicine, 6 (6), 17, 2002.

46. ROD S., HUA C.L., WANG X.G. Changes of antioxidative activities in blood of low-selenium animals, Chinese Journal of Public Health, 15 (1), 52, 1996
47. PENG X. Mechanisms of the immune functional impairment caused by dietary selenium in chickens. Sichuan Agricultural University, pp. 3, 2009.

48. CAO Y., LI L., ZHANG H.Y. Study of blood clinical pathological changes of selenium deficiency of dairy cattle in intensive dairy farm. Journal of Heilongjiang Bayi Agricultural University, 28 (6), 49, 2016.

49. LEI X.U., WU D., FEI C.L. Measurement of blood cell and blood biochemical in selenium-deficiency zebras. Sichuan Journal of Zoology, 35 (01), 113, 2016.

50. ŻARCZYNSKA K., BAUMGARTNER W., SOBIECH P. Coagulology, biochemical profile and muscle pathology in calves diagnosed with nutritional muscular dystrophy. Polish Journal of Veterinary Sciences, 20 (2), 387, 2017.

51. WU L., XIA C., ZHANG H.Y., XU C., YANG W., ZHENG J.S. Plasma Se level and its relationship with antioxidant and immune function in lactation cows. Chinese Journal of Veterinary Science, 35 (12), 1974, 2015.

52. XU L., WU D.H., CHEN F.L. Measurement of blood cell and blood biochemical in selenium-deficiency zebras. Sichuan Journal of Zoology, 28 (06), 49, 2016.

53. SUTTLE N.F. Selenium. In: suttle NF(ed) mineral nutrition of livestock [M]. CABI, pp. 377, 2010.

54. ADEBAYO O.L., ADENUGA G.A., SANDHIR R. Selenium and zinc protect brain mitochondrial antioxidants and electron transport chain enzymes following postnatal protein malnutrition. Life Sciences, 152 (1), 145, 2016.

55. JIN X., XU Z., ZHAO X. The antagonistic effect of selenium on lead-induced apoptosis via mitochondrial dynamics pathway in the chicken kidney. Chemosphere, 180 (1), 259, 2017.

56. LUAN Y., ZHAO J., YAO H. Selenium deficiency influences the mRNA expression of selenoproteins and cytokines in chicken erythrocytes. Biological Trace Element Research, 171 (2), 427, 2016.

57. YANG J., HAMID S., LIU Q. Gene expression of selenoproteins can be regulated by thioredoxin (Txn) silence in chicken cardiomyocytes. Journal of Inorganic Biochemistry, 177, 118, 2017.

58. HUANG J.Q., REN F.Z., JIANG Y.Y., XIAO C., LEI X.G. Selenoproteins protect against avian nutritional muscular dystrophy by metabolizing peroxides and regulating redox/ apoptotic signaling. Free Radical Biology and Medicine, 83, 129, 2015. 
